University of Nebraska - Lincoln

DigitalCommons@University of Nebraska - Lincoln

Faculty Publications: Department of Entomology

1999

\title{
Identification of Muscidifurax Spp. by Polymerase Chain Reaction- Restriction Fragment Length Polymorphism
}

David B. Taylor

University of Nebraska-Lincoln, dave.taylor@ars.usda.gov

Allen L. Szalanski

University of Nebraska-Lincoln

Follow this and additional works at: https://digitalcommons.unl.edu/entomologyfacpub

Part of the Entomology Commons

Taylor, David B. and Szalanski, Allen L., "Identification of Muscidifurax Spp. by Polymerase Chain ReactionRestriction Fragment Length Polymorphism" (1999). Faculty Publications: Department of Entomology. 203.

https://digitalcommons.unl.edu/entomologyfacpub/203

This Article is brought to you for free and open access by the Entomology, Department of at DigitalCommons@University of Nebraska - Lincoln. It has been accepted for inclusion in Faculty Publications: Department of Entomology by an authorized administrator of DigitalCommons@University of Nebraska - Lincoln. 


\title{
Identification of Muscidifurax Spp. by Polymerase Chain Reaction-Restriction Fragment Length Polymorphism
}

\author{
David B. Taylor* and Allen L. Szalanski $\dagger$ \\ *USDA, ARS Midwest Livestock Insects Research Laboratory, Department of Entomology, and $\dagger$ Department of Plant Pathology, \\ University of Nebraska, Lincoln, Nebraska 68583
}

Received September 2, 1998; accepted February 5, 1999

\begin{abstract}
Polymerase chain reaction-restriction fragment length polymorphism (PCR-RFLP) analysis of the nuclear ribosomal ITS-1 region was used to differentiate Muscidifurax (Hymenoptera: Pteromalidae) species which are parasitoids of filth fly pupae. Three restriction enzymes, Dpn II, Mse I, and Taq I, produced restriction patterns which were diagnostic for the four species analyzed, $M$. raptor, $M$. raptorellus, $M$. uniraptor, and $M$. zaraptor. Seven other restriction enzymes were able to differentiate one or more of the species and can be used alone, or in combination with other enzymes, to verify identifications. No intraspecific variation was observed among the populations examined. The utility of the PCR-RFLP technique compared with other molecular and biochemical diagnostic procedures is discussed. 1999 Academic Press

Key Words: PCR-RFLP; molecular diagnostics; Muscidifurax; filth fly parasitoids; Pteromalidae.
\end{abstract}

\section{INTRODUCTION}

Wasps in the genus Muscidifurax are among the most promising biological control agents for flies breeding in the confined livestock environment (Miller and Rutz, 1990; Petersen et al., 1990). The genus contains five species, four of which have been used for biological control. Because of their small size, differentiating the species can be difficult. In fact, only one species, $M$. raptor Girault \& Sanders was recognized prior to 1970 (Kogan and Legner, 1970). Although morphologically similar, each of the Muscidifurax species has unique biological characteristics, which make accurate identification important. In addition, differentiating released species from native wasps is important for evaluating the impact and efficacy of augmentive releases for biological control.

Several techniques have been used for molecular diagnostics of insect species, each with its own intrinsic advantages and disadvantages. Among the most popu- lar techniques are randomly amplified polymorphic DNA (RAPD-PCR) (Kambhampati et al., 1992; Wilkerson et al., 1995; Antolin et al., 1996), polymerase chain reaction-restriction fragment length polymorphism (PCR-RFLP) of nuclear (Slade et al., 1993; Pfeifer et al., 1995) and mitochondrial (Sperling et al., 1994; Taylor et al., 1996; Roehrdanz, 1997) genomes, and speciesspecific PCR primers (Scott et al., 1993) and probes (Haymer et al., 1994). We chose PCR-RFLP for this study because the technique is simple and inexpensive, very reliable and repeatable, and provides discrete character states, which can be used for phylogenetic analyses as well as diagnostics.

PCR-RFLP and sequencing analyses of a portion of the mitochondrial genome of Muscidifurax species (Taylor et al., 1997) revealed several restriction patterns diagnostic between $M$. raptor and $M$. raptorellus Kogan \& Legner. However, $M$. uniraptor Kogan \& Legner was identical to $M$. raptorellus and multiple $(>20)$ restriction patterns were observed from individual $M$. zaraptor Kogan \& Legner, apparently caused by multiple or repeated translocations of the mitochondrial sequence to the nuclear genome.

The nuclear ribosomal intergenic transcribed spacer (ITS-1) has proved useful for differentiating species (Pfeifer et al., 1995; Powers et al., 1997; Szalanski et al., 1997). This region diverges at a rate 3-4 times faster than mitochondrial DNA in reproductively isolated populations (Marçon et al., 1999), but, in general, the repeats remain relatively homogeneous within individuals and populations (Zimmer et al., 1980; Elder and Turner, 1995). Rapid divergence and concerted evolution make the ITS region ideal for molecular diagnostics.

The purpose of this study was to identify species diagnostic characters for the four species of Muscidifurax used for biological control of filth flies. The fifth species, $M$. raptoroides Kogan \& Legner, has not been used for biological control in North America nor has it been colonized. 
TABLE 1

Strains of Muscidifurax spp. Used in This Study

\begin{tabular}{|c|c|c|c|c|}
\hline Species & $N$ & Origin & $\begin{array}{l}\text { Date colony } \\
\text { established }\end{array}$ & Source \\
\hline \multirow{3}{*}{ M. raptor } & 3 & Nebraska & 1995 & MLIRL $^{a}$ \\
\hline & 3 & New York & Unknown & Cornell University \\
\hline & 5 & $\begin{array}{l}\text { Alberta, } \\
\text { Canada }\end{array}$ & 1995 & Ag Canada, Lethbridge \\
\hline \multirow[t]{3}{*}{ M. raptorellus } & 3 & Chile & Unknown & Legner via MLIRL $^{b}$ \\
\hline & 3 & Nebraska & 1991 & MLIRL $^{a}$ \\
\hline & 3 & Peru & Unknown & Legner via MLIRL $^{b}$ \\
\hline M. uniraptor & 3 & Puerto Rico & Unknown & Rochester University \\
\hline \multirow[t]{2}{*}{ M. zaraptor } & 3 & Nebraska & 1993 & MLIRL $^{a}$ \\
\hline & 7 & $\begin{array}{l}\text { Alberta, } \\
\text { Canada }\end{array}$ & 1995 & Ag Canada, Lethbridge \\
\hline
\end{tabular}

${ }^{\alpha}$ Midwest Livestock Insect Research Laboratory, USDA-ARS, Lincoln, NE.

${ }^{b}$ Originally collected by E. F. Legner and transferred to MLIRL in 1989.

\section{MATERIALS AND METHODS}

Techniques used for this study were similar to those used by Taylor et al., 1996. DNA was isolated from frozen and alcohol-preserved specimens using the phenol/chloroform extraction with ethanol precipitation. The ITS-1 region was amplified with the primers rDNA $_{2}$ (TTGATTACGTCCCTGCCCTTT; Vrain et al., 1992) and rDNA $_{1.58 s}$ (ACGAGCCGAGTGATCCACCG; Cherry et al., 1997). The PCR protocol was 35 cycles of $94^{\circ} \mathrm{C}$ for $45 \mathrm{~s}, 52^{\circ} \mathrm{C}$ for $1 \mathrm{~min}$, and $72^{\circ} \mathrm{C}$ for $2 \mathrm{~min}$. Amplicons were digested with 27 restriction enzymes (RE, Alu I, Apo I, Ase I, Ava I, Ban II, Bfa I, Bsr I, Dde I, Dpn II, Dra I, Ecl136 II, EcoR I, EcoR V, Hae III, Hinc II, Hind III, HinfI, Hpa I, Mse I, Msp I, Pvu II, Rsa I, Sau96 I, ScrfI, Ssp I, Taq I, and Xba I). Digest products were separated by polyacrylamide $(10 \%)$ and agarose (2.5\% MetaPhor) gel electrophoresis. Gels were stained with ethidium bromide and photographed with ultraviolet illumination. A 50-bp ladder was included on each gel. Fragment lengths were estimated with the computer program GEL-JML (LaCroix, 1994). Wasp samples examined are presented in Table 1.

\section{RESULTS}

The ITS-1 amplicon was approximately $980 \mathrm{bp}$ long for all four species of Muscidifurax. Thirteen restriction enzymes, Alu I, Ase I, Ava I, Ban II, Bfa I, Ecl136 II, EcoR I, EcoR V, Hinc II, Hind III, Hpa I, Pvu II, and $X b a \mathrm{I}$, failed to cut this amplicon. Fragment patterns for the remaining 14 REs are presented in Table 2. No intraspecific variation was observed in the samples examined. Digest patterns for four REs, Apo I, Msp I, Sau96 I, and $S s p$ I, were similar for all four species. Three REs, Dpn II, Mse I, and Taq I, produced patterns which differentiated all four species (Fig. 1). Three REs produced unique digest patterns for one species, Dde I for $M$. raptor, Bsr I for M. raptorellus, and Dra I for $M$. uniraptor. HinfI, Rsa I, and ScrfI differentiated $M$. raptor and $M$. zaraptor from $M$. raptorellus and $M$. uniraptor. HinfI was also able to differentiate $M$. raptorellus from $M$. uniraptor.

\section{DISCUSSION}

Muscidifurax species can be easily differentiated with Dpn II, Mse I, and Taq I digests of the nuclear ribosomal ITS-1 region. Species identification can be verified by the use of several other enzymes either alone or in combination. Mse I is the most useful enzyme for differentiating these species because all

TABLE 2

Restriction Fragment Lengths Estimated on 2.5\% Metaphor Agarose Gels for Muscidifurax Species

\begin{tabular}{lllll}
\hline \multicolumn{1}{c}{ RE } & \multicolumn{1}{c}{ M. raptor } & \multicolumn{1}{c}{ M. raptorellus } & \multicolumn{1}{c}{ M. uniraptor } & \multicolumn{1}{c}{ zaraptor } \\
\hline Apo I & $404,{ }^{a} 353,187,32$ & $404,353,187,32$ & $404,353,187,50$ & $404,353,187,32$ \\
Bsr I & 903,84 & $620,280,84$ & 903,84 & 903,84 \\
Dde I & 510,470 & 980 & 980 & 980 \\
Dpn II & $335,245,135,112,92,60$ & $335,245,135,112,82,62$ & $150,^{a} 135,{ }^{a} 112,103,54$ & $335,245,135,112,103,60$ \\
Dra I & 716,257 & 716,257 & $626,364,97,48$ & 716,257 \\
EcoR I & 980 & 980 & 980 & $980,590,390$ \\
Hae III & $390,306,163,101$ & $390,306,163,101$ & $510,306,160$ \\
Hinf I & $337,{ }^{a} 202,97$ & $491,285,202$ & $390,306,163,101$ & $337,{ }^{a} 194,97$ \\
Mse I & $275,215,195,181,65$ & $370,192,192,90,62,55$ & $416,194,108,,^{a} 62,43$ & $522,194,171,64$ \\
Msp I & $344,286,246,117$ & $332,283,254,117$ & $341,283,256,117$ & $338,286,260,117$ \\
Rsa I & $450,426,73,24$ & $450,392,75,26,24$ & $450,389,76,26$ & $450,426,79,24$ \\
Sau 96 I & 560,406 & 560,406 & 560,406 & 560,406 \\
Scrf I & 965 & 854,115 & 854,115 & 965 \\
Ssp I & 718,243 & 718,243 & 718,243 & 718,243 \\
Taq I & $543,263,156$ & $503,283,156,36$ & $522,283,156,46$ & $355,283,156,79,72,37$ \\
\hline
\end{tabular}

\footnotetext{
${ }^{a}$ Interpreted as double bands.
} 


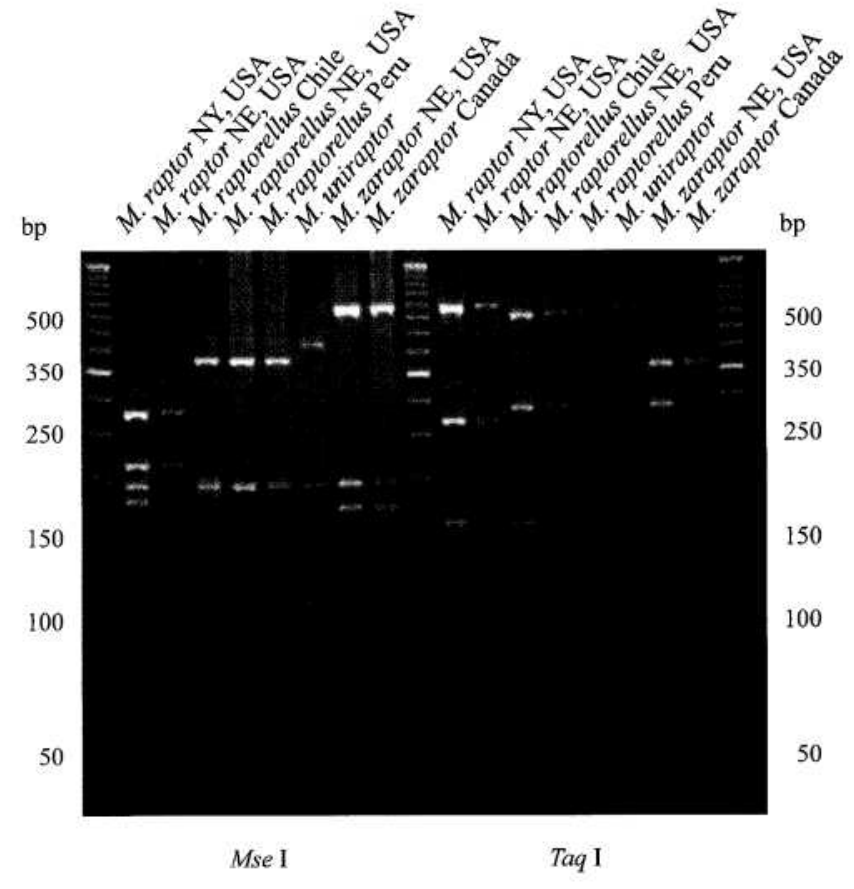

FIG. 1. Mse I and Taq I digests of Muscidifurax spp. ITS-1 amplicon on $2.5 \%$ MetaPhor agarose gels.

four species can be characterized by unique fragments larger than $100 \mathrm{bp}$. Differentiating $M$. raptorellus and $M$. uniraptor with Dpn II and Taq I is primarily dependent upon smaller fragments, which can be difficult to visualize under less than optimal PCR and electrophoretic conditions.

Because our sample sizes are relatively small, it is possible that undetected intraspecific variation may compromise some of the diagnostic restriction sites. However, one of the major advantages of the PCRRFLP technique is that multiple discrete characters are available for diagnostic purposes. Even if undetected variation reduces the usefulness of one restriction site, others can be used to verify the identification. Additional advantages of the PCR-RFLP technique are that fragment patterns will be observed for all species, whether they have been previously characterized or not. These patterns can be associated with the correct species at a later date, without having to reanalyze the specimen. This characteristic is also valuable for detecting previously unrecognized cryptic species. Like PCRRFLP, RAPD-PCR produces specific patterns that may be used for later identification of uncharacterized species. However, RAPD-PCR banding patterns can vary with DNA quality and quantity as well as amplification protocols and even thermocyclers (Black, 1993). Problems with reproducibility of banding patterns among samples of varying quality and among laboratories make RAPD-PCR a less than optimal choice for general species diagnostics. Other diagnostic techniques, such as species-specific PCR primers, probes, and ELISA (Ma et al., 1990), require that unidentified samples be reanalyzed with new reagents as they become available to reach a positive identification. Also, because PCRRFLP involves two steps, amplification followed by digestion, false negative identifications due to sample or reagent degradation are avoided. Failure of the PCR step indicates that the specimen is unidentifiable, probably because of sample degradation. Other techniques, such as species-specific primers and probes and ELISA, rely upon the quality of the sample for the identification step of the analysis. The lack of the positive reaction may be due to either the sample not being the target species or the sample being degraded. In ecological studies, in which a large number of samples are available and individual errors are not critical, these techniques may be acceptable. However, when identifying quarantine pests, forensic samples, or in other situations in which the number of samples is limited and error, especially false negative, is unacceptable, we believe that the PCR-RFLP technique is superior. PCR-RFLP can be used to identify samples preserved with most commonly used preservatives as well as dried-pinned specimens (Taylor et al., 1996).

\section{ACKNOWLEDGMENTS}

We thank K. Floate, W. Watson, and J. H. Werren for samples and T. O. Powers for permitting us to do some aspects of this work in his laboratory. K. Pruess and B. Siegfried provided helpful suggestions and critical reviews of the manuscript. This work was done in cooperation with the Institute of Agriculture and Natural Resources, University of Nebraska, Lincoln, and is published as Journal Series, Nebraska Agricultural Research Division Paper 12277.

\section{REFERENCES}

Antolin, M. F., Guertin, D. S., and Petersen, J. J. 1996. The origin of gregarious Muscidifurax (Hymenoptera: Pteromalidae) in North America: An analysis using molecular markers. Biol. Contr. 6, $76-82$.

Cherry, T., Szalanski, A. L., Todd, T. C., and Powers, T. O. 1997. The internal transcribed spacer region of Belonolaimus (Nemata: Belonolaimidae). J. Nematol. 29, 23-29.

Elder, J. F., and Turner, B. J. 1995. Concerted evolution of repetitive DNA sequences in eukaryotes. Q. Rev. Biol. 70, 297-320.

Haymer, D. S., Tanaka, T., and Teramae, C. 1994. DNA Probes can be used to discriminate between tephritid species at all stages of the life cycle (Diptera, Tephritidae). J. Econ. Entomol. 87, 741-746.

Kambhampati, S., Black, W. C., IV, and Rai, K. S. 1992. Random amplified polymorphic DNA of mosquito species and populations (Diptera: Culicidae): Techniques, statistical analysis, and applications. J. Med. Entomol. 29, 939-945.

Kogan, M., and Legner, E. F. 1970. A biosystematic revision of the genus Muscidifurax (Hymenoptera: Pteromalidae) with descriptions of four new species. Can. Entomol. 102, 1268-1290.

LaCroix, J. M. 1994. DNA fragment size determination on agarose gel by using the application GEL. Computer Appl. Biosci. 10, 185-187.

Ma, M., Beier, J. C., Petrarca, V., Gwadz, R. W., Zhang, J.-Z., Song, Q., and Koech, D. K. 1990. Differentiation of Anopheles gambiae and 
An. arabiensis (Diptera: Culicidae) by ELISA using immunoaffinitypurified antibodies to vitellogenin. J. Med. Entomol. 27, 564-569.

Marçon, P. C. R. G., Taylor, D. B., Mason, C. E., Hellmich, R. L., and Siegfried, B. D. 1999. Genetic similarity among pheromone and voltinism races of Ostrinia nubilalis (Hübner) (Lepidoptera: Pyralidae). Insect Mol. Biol., in press.

Miller, R. W., and Rutz, D. A. 1990. Survey of house fly pupal parasitoids on dairy farms in Maryland and New York. In "Biocontrol of Arthropods Affecting Livestock and Poultry" (D. A. Rutz and R. S. Patterson, Eds.), pp. 59-67. Westview, Boulder, CO.

Petersen, J. J., Watson, D. W., and Pawson, B. M. 1990. Native biocontrol agents as a component of integrated pest management for confined livestock. In "Biocontrol of Arthropods Affecting Livestock and Poultry" (D. A. Rutz and R. S. Patterson, Eds.), pp. 79-93. Westview, Boulder, CO.

Pfeifer, T. A., Humble, L. M., Ring, M., and Grigliatti, T. A. 1995. Characterization of gypsy moth populations and related species using a nuclear DNA marker. Can. Entomol. 127, 49-58.

Powers, T. O., Todd, T. C., Burnell, A. M., Murray, P. C. B., Fleming, C. C., Szalanski, A. L., Adams, B. A., and Harris, T. S. 1997. The rDNA internal transcribed spacer region as a taxonomic marker for nematodes. J. Nematol. 29, 441-450.

Roehrdanz, R. L. 1997. Identification of tobacco budworm and corn earworm (Lepidoptera: Noctuidae) during early developmental stages by polymerase chain reaction and restriction fragment length polymorphism. Ann. Entomol. Soc. Am. 90, 329-332.

Scott, J. A., Brogdon, W. G., and Collins, F. H. 1993. Identification of single specimens of the Anopheles gambiae complex by the polymerase chain reaction. Am. J. Trop. Med. Hyg. 49, 520-529.
Slade, R. W., Moritz, C., Heideman, A., Hale, P. T. 1993. Rapid assessment of single-copy nuclear DNA variation in diverse species. Mol. Ecol. 2, 359-373.

Sperling, F. A. H., Anderson, G. S., and Hickey, D. A. 1994. A DNA-based approach to the identification of insect species used for postmortem interval estimation. J. Forensic Sci. 39, 418-427.

Szalanski, A. L., Sui, D. D., Harris, T. S., and Powers, T. O. 1997. Identification of cyst nematodes of agronomic and regulatory concern by PCR-RFLP of ITS1. J. Nematol. 29, 253-264.

Taylor, D. B., Szalanski, A. L., and Peterson, R. D. 1996. Identification of screwworm species by polymerase chain reaction-restriction fragment length polymorphism. Med. Vet. Entomol. 10, 63-70.

Taylor, D. B., Peterson, R. D., Szalanski, A. L., and Petersen, J. J. 1997. Mitochondrial DNA variation among Muscidifurax spp. (Hymenoptera: Pteromalidae), pupal parasitoids of filth flies. Ann. Entomol. Soc. Am. 90, 814-824.

Vrain, T. C., Wakarchuk, D. A., Levesque, A. C., and Hamilton, R. I. 1992. Intraspecific rDNA restriction fragment length polymorphism in the Xiphinema americanum group. Fund. Appl. Nematol. 15, 563-573.

Wilkerson, R. C., Parsons, T. J., Klein, T. A., Gaffigan, T. V., Bergo, E., and Consolim, J. 1995. Diagnosis by random amplified polymorphic DNA polymerase chain reaction of four cryptic species related to Anopheles (Nyssorhynchus) albitarsis (Diptera: Culicidae) from Paraguay, Argentina, and Brazil. J. Med. Entomol. 32, 697-704.

Zimmer, E. A., Martin, S. L., Beverly, S. M., Kan, Y. W., and Wilson, A. C. 1980. Rapid duplication and loss of genes coding for the $\alpha$ chains of hemoglobin. Proc. Natl. Acad. Sci. USA 77, 2158-2162. 